\title{
Active Polycondensation of Dicarboxylic Acid Derivatives Having $\beta$-Hetero Atoms
}

\author{
Naoya Ogata, Kohei Sanui, and Kazuo Okouchi \\ Department of Chemistry, Sophia University \\ Chiyoda-ku, Tokyo, Japan.
}

(Received March 8, 1973)

\begin{abstract}
Diesters or dibasic acids having hetero atoms at positions $\beta$ to the carbonyl group underwent polycondensation reaction with diamines to form polyamide under mild conditions at relatively low temperature either in solution or in the solid phase. The reactivity enhancement of diesters or dibasic acids due to the introduction of $\beta$-hetero atoms could be arranged in the same order of electronegativities: $-\mathrm{O}-\geqslant$ $-\mathrm{S}->-\mathrm{N}=>-\mathrm{SO}_{2}->-\mathrm{P}=$.

The effect of these hetero atoms on the reactivity was presumed to be due to the intramolecular interaction between the hetero atoms and the carbonyl group of the ester or acid.
\end{abstract}

KEY WORDS Polycondensation / Diester / Dicarboxylic Acid /

Diamine / $\beta$-Hetero Atoms / Piperazine /

Polycondensation reactions are generally addition-elimination reactions accompanied by an equilibrium with the apparent rates of the reactions controlled by the equilibrium. Thus, the elimination from the reaction system of volatile byproducts such as water is apparently a ratedetermining factor in driving the reaction to completion. A larger equilibrium constant is favorable to the formation of a polymer with a high molecular weight. Therefore, polycondensation reactions are usually carried out at elevated temperatures above the melting points of resulting polymers so as to shift the equilibrium toward polymer formation by the removal of volatile by-products.

On the other hand, it has recently been found that the polycondensation reaction can proceed under mild conditions if the reactivity of the functional groups such as amine or carboxylic acid is enhanced by introducing activating substituents to such an extent that the equilibrium is shifted toward the formation of polymers. For instance, active esters such as phenyl or thiophenyl esters are known ${ }^{1,2}$ to cause polycondensation reactions under mild conditions, and amino acid esters having thioether groups easily form polyamide thioether in the presence of a basic catalyst at room temperature. ${ }^{3,4}$ This peculiar behavior of active esters having a $\beta$-sulfur atom, such as the polycondensation of methyl 4-thio- $\varepsilon$-aminocaproate $\mathrm{NH}_{2} \mathrm{CH}_{2} \mathrm{CH}_{2} \mathrm{SCH}_{2} \mathrm{CH}_{2}$ $\mathrm{COOCH}_{3}$, stimulated us to systematically study the polycondensation reactions of acid derivatives having various hetero atoms at the position $\beta$ to the carbonyl group so that the polycondensation takes place under mild conditions without heating the monomers to high temperatures.

\section{EXPERIMENTAL}

\section{Synthesis of Monomers}

The following diesters with $\beta$-hetero atoms of oxygen, sulfur, nitrogen or phosphorous were synthesized by the addition reaction of the corresponding bifunctional compounds with acrylates:

$$
\begin{array}{r}
\mathrm{HX}-\mathrm{R}-\mathrm{XH}+2 \mathrm{CH}_{2}=\mathrm{CHCOOR}{ }^{\prime} \\
\longrightarrow \mathrm{R}^{\prime} \mathrm{OOCCH}_{2} \mathrm{CH}_{2} \mathrm{X}-\mathrm{R}-\mathrm{XCH}_{2} \mathrm{CH}_{2} \mathrm{COOR}^{\prime} \\
\left(\mathrm{X}: \mathrm{O}, \mathrm{S}, \mathrm{SO}_{2}, \mathrm{~N}, \text { or } \mathrm{P}\right)
\end{array}
$$

Free dibasic acids were obtained by the alkaline hydrolysis of the corresponding diesters and were isolated by passing the hydrolyzed aqueous solutions through ion exchange resins (cationic and anionic), followed by evaporation of water.

Oxidation of thioether or phosphite groups to sulfone or phosphate groups, respectively, was 
Active Polycondensation

carried out by the oxidation of the corresponding monomers with hydrogen peroxide in acetone solution. The physical properties and abbrevi- ations for the synthesized monomers are as shown below.
I. $\mathrm{CH}_{3} \mathrm{OOCCH}_{2} \mathrm{CH}_{2} \mathrm{OCH}_{2} \mathrm{CH}_{2} \mathrm{OCH}_{2} \mathrm{CH}_{2} \mathrm{COOCH}_{3}$ :

II. $\mathrm{CH}_{3} \mathrm{OOCCH}_{2} \mathrm{CH}_{2} \mathrm{SCH}_{2} \mathrm{CH}_{2} \mathrm{COOCH}_{3}$ :

III. $\mathrm{CH}_{3} \mathrm{OOCCH}_{2} \mathrm{CH}_{2} \mathrm{~S}\left(\mathrm{CH}_{2}\right)_{4} \mathrm{SCH}_{2} \mathrm{CH}_{2} \mathrm{COOCH}_{3}$ :

IV. $\mathrm{CH}_{3} \mathrm{OOCCH}_{2} \mathrm{CH}_{2} \mathrm{~S}-\langle\rangle-\left\langle-\mathrm{SCH}_{2} \mathrm{CH}_{2} \mathrm{COOCH}_{3}\right.$ :

V. $\mathrm{CH}_{3} \mathrm{OOCCH}_{2} \mathrm{CH}_{2} \mathrm{~N} \mathrm{NCH}_{2} \mathrm{CH}_{2} \mathrm{COOCH}_{3}$ :

VI. $\mathrm{C}_{2} \mathrm{H}_{5} \mathrm{OOCCH}_{2} \mathrm{CH}_{2} \mathrm{~N} \mathrm{NCH}_{2} \mathrm{CH}_{2} \mathrm{COOC}_{2} \mathrm{H}_{5}$ :

VII. $\mathrm{C}_{4} \mathrm{H}_{9} \mathrm{OOCCH}_{2} \mathrm{CH}_{2} \mathrm{~N} \mathrm{NCH}_{2} \mathrm{CH}_{2} \mathrm{COOC}_{4} \mathrm{H}_{9}$ :

VIII. $\mathrm{C}_{6} \mathrm{H}_{5} \mathrm{OOCCH}_{2} \mathrm{CH}_{2} \mathrm{~N} \mathrm{NCH}_{2} \mathrm{CH}_{2} \mathrm{COOC}_{6} \mathrm{H}_{5}$ :

$$
\mathrm{CH}_{3}
$$

IX. $\mathrm{C}_{6} \mathrm{H}_{5} \mathrm{OOCCH}_{2} \mathrm{CH}_{2} \mathrm{~N} \quad \mathrm{NCH}_{2} \mathrm{CH}_{2} \mathrm{COOC}_{6} \mathrm{H}_{5}$ : $\mathrm{CH}_{3}$

X. $\mathrm{CH}_{3} \mathrm{OOCCH}_{2} \mathrm{CH}_{2} \mathrm{NCH}_{2} \mathrm{CH}_{2} \mathrm{NCH}_{2} \mathrm{CH}_{2} \mathrm{COOCH}_{3}$ : $\stackrel{\mid}{\mathrm{CH}_{3}} \quad \mathrm{CH}_{3}$

XI. $\mathrm{CH}_{3} \mathrm{OOCCH}_{2} \mathrm{CH}_{2} \mathrm{NCH}_{2} \mathrm{CH}_{2} \mathrm{NCH}_{2} \mathrm{CH}_{2} \mathrm{COOCH}_{3}$ :<smiles>CCCCCCCC</smiles>

XII. $\mathrm{CH}_{3} \mathrm{OOCCH}_{2} \mathrm{CH}_{2} \mathrm{~N}\left(\mathrm{CH}_{2}\right)_{6} \mathrm{NCH}_{2} \mathrm{CH}_{2} \mathrm{COOCH}_{3}$ :<smiles>C[14CH][14CH](C)[14CH2][14CH3]</smiles>

XIII. $\mathrm{CH}_{3} \mathrm{OOCCH}_{2} \mathrm{CH}_{2} \mathrm{PCH}_{2} \mathrm{CH}_{2} \mathrm{COOCH}_{3}$ :<smiles>c1ccccc1</smiles>

XIV. $\mathrm{C}_{6} \mathrm{H}_{5} \mathrm{OOCCH}_{2} \mathrm{CH}_{2} \mathrm{PCH}_{2} \mathrm{CH}_{2} \mathrm{COOC}_{6} \mathrm{H}_{5}$ :<smiles>[TlH2]c1ccccc1</smiles><smiles>[Y]#CCCC(=O)CCC(=O)OC</smiles>

XVI. $\mathrm{HOOCCH} \mathrm{CH}_{2} \mathrm{SCH}_{2} \mathrm{CH}_{2} \mathrm{COOH}$ :

XVII. HOOCCH $\mathrm{CH}_{2} \mathrm{SCH}_{2} \mathrm{CH}_{2} \mathrm{SCH}_{2} \mathrm{CH}_{2} \mathrm{COOH}$ :

XVIII. HOOCCH $\mathrm{CH}_{2} \mathrm{SO}_{2} \mathrm{CH}_{2} \mathrm{CH}_{2} \mathrm{SO}_{2} \mathrm{CH}_{2} \mathrm{CH}_{2} \mathrm{COOH}$ :

XIX. $\mathrm{HOOCCH} \mathrm{CH}_{2} \mathrm{OCH}_{2} \mathrm{CH}_{2} \mathrm{OCH}_{2} \mathrm{CH}_{2} \mathrm{COOH}$ :

$\mathrm{XX}$. $\mathrm{HOOCCH}_{2} \mathrm{CH}_{2} \mathrm{~N} \mathrm{NCH}_{2} \mathrm{CH}_{2} \mathrm{COOH}$ : bp $136-138^{\circ} \mathrm{C}(0.7 \mathrm{~mm})$

C, $52.3 \%(51.7) ; \mathrm{H}, 6.82 \%(6.90)$

bp $163-164^{\circ} \mathrm{C}(19 \mathrm{~mm})$

[lit. $\left.162-164^{\circ} \mathrm{C}(18 \mathrm{~mm})\right]^{5}$

bp $165-170^{\circ} \mathrm{C}(2 \mathrm{~mm})$

C, $48.3 \%$ (49.0); H, 7.42\%(7.48)

$\mathrm{mp} 106-108^{\circ} \mathrm{C}$

$\mathrm{C}, 61.1 \%(61.5), \mathrm{H}, 5.68 \%(5.64)$

$\mathrm{mp} 54^{\circ} \mathrm{C}$

$\mathrm{N}, 10.70 \%(10.86)$

bp $170-174^{\circ} \mathrm{C}(2 \mathrm{~mm})$

$\mathrm{N}, 9.77 \%(9.72)$

bp $184-187^{\circ} \mathrm{C}(2 \mathrm{~mm})$

$\mathrm{N}, 8.12 \%(8.12)$

$\mathrm{mp} 105^{\circ} \mathrm{C}$

$\mathrm{N}, 7.30 \%(7.33)$

$\mathrm{mp} 87^{\circ} \mathrm{C}$

$\mathrm{N}, 6.80 \%(6.83)$

bp $180^{\circ} \mathrm{C}(15 \mathrm{~mm})$

$\mathrm{N}, 10.80 \%(10.76)$

bp $123-124^{\circ} \mathrm{C}(13 \mathrm{~mm})$

$\mathrm{N}, 9.74 \%(9.72)$

bp $105^{\circ} \mathrm{C}(2 \mathrm{~mm})$

$\mathrm{N}: 9.02 \%(8.81)$

bp $155-160^{\circ} \mathrm{C}(2 \mathrm{~mm})$

C, 60.14\%(59.57); H, 6.95\%(6.78)

mp $34-36^{\circ} \mathrm{C}$,

bp $48-52^{\circ} \mathrm{C}(3 \mathrm{~mm})$

C, $71.42 \%(70.93) ; \mathrm{H}, 5.85 \%(5.71)$

bp $200-220^{\circ} \mathrm{C}(1 \mathrm{~mm})$

C, 55.71\%(56.37); H, 6.57\%(6.42)

mp $134^{\circ} \mathrm{C}$ (lit. $\left.134^{\circ} \mathrm{C}\right)^{6}$

mp $154-156^{\circ} \mathrm{C}$

C, 41.85\%(40.34); H, 4.57\%(4.79)

$\mathrm{mp}>250^{\circ} \mathrm{C}$

$\mathrm{C}, 32.48 \%(32.87) ; \mathrm{H}, 4.57 \%(4.79)$

grease

C, $47.45 \%(47.50) ; \mathrm{H}, 6.95 \%(6.93)$

$\mathrm{mp} 192-194^{\circ} \mathrm{C}$

$\mathrm{N}, 11.92 \%(12.17)$ 


\section{Solution and Bulk Polycondensation}

Solution polycondensations of these diesters or dibasic acids with diamines were carried out in various solvents at a desired concentration. The rate of the polycondensation was determined by the residual amount of amine which was measured by titration, or by gaschromatographic analysis for alcohol liberated into the solutions. In some cases, polymer yields were measured from the amount of polymers which were isolated by pouring the polymer solutions into acetone, filtering and drying.

Bulk polycondensations of diesters with diamines were carried out at 60,100 or $110^{\circ} \mathrm{C}$ in sealed tubes. The polymers were collected by washing the products with acetone and the amounts of acetone-insoluble polymers were weighed.

\section{Solid-Phase Polycondensation}

Nylon salts with 100 mesh sizes which were obtained by mixing alcoholic solutions of dibasic acids with those of diamines, were heated at 100 or $150^{\circ} \mathrm{C}$ under nitrogen atmosphere. The melting points and elementary analyses of the nylon salts from monomers XVI, XVII, XVIII, XIX and XX with hexamethylenediamine (HMD) are as shown below:

$\mathrm{XVI} / \mathrm{HMD}: \mathrm{mp} 181-182^{\circ} \mathrm{C} ; \mathrm{C}, 48.5 \%(49.0)$; $\mathrm{H}, 8.70 \%(8.84) ; \mathrm{N}, 9.32 \%(9.52)$

XVII/HMD: $\mathrm{mp} 168^{\circ} \mathrm{C}$; C, 52.0\%(52.2); H, 9.12\%(9.32); N, 8.50\%(8.69)

XVIII/HMD: $\operatorname{mp~} 188^{\circ} \mathrm{C}, \mathrm{C}: 41.0 \%(40.2) ; \mathrm{H}$, $7.10 \%(7.18) ; \mathrm{N}, 6.65 \%(6.70)$

XIX/HMD: $\operatorname{mp~} 156-159^{\circ} \mathrm{C} ; \mathrm{C}, 52.3 \%(52.2)$; $\mathrm{H}, 10.03 \%(9.32) ; \mathrm{N}, 9.34 \%(8.69)$

$\mathrm{XX} / \mathrm{HMD}: \mathrm{mp} 163-165^{\circ} \mathrm{C}$; C, $55.3 \%(55.5)$; $\mathrm{H}, 9.56 \%(9.83) ; \mathrm{N}, 15.9 \%(16.3)$

The polymers were obtained by washing the reaction products with acetone after heating the nylon salts for the desired period of time.

\section{Polymer Characterization}

The polymers were analyzed by infrared spectroscopy and elementary analyses. Molecular weights of the polymers were measured by endgroup titrations according to the conventional methods. Solution viscosities of the polymers were determined in $96-\%$ sulfuric acid at a concentration of $0.1 \mathrm{~g} / 10 \mathrm{ml}$ at $30^{\circ} \mathrm{C}$.

\section{RESULTS AND DISCUSSION}

\section{Polycondensation of Active Diesters}

Monomers Having $\beta$-Oxygen or $\beta$-Sulfur Atoms.

Monomers I, II, III or IV were subjected to polycondensation reactions with hexamethylenediamine in various solvents at $30^{\circ} \mathrm{C}$. The rates of polycondensation in terms of the amount of residual amine are shown in Figures 1 and 2, and properties of the polymers obtained after a prolonged period of polycondensation are summarized in Table I.

As indicated in Figures 1 and 2, the polycondensation reactions at $30^{\circ} \mathrm{C}$ proceeded with such a slow rate that the polycondensation was still taking place even after one month. The rates for polycondensation of monomers having $\beta$-oxygen or -sulfur atoms increased in a protonic dipolar solvent such as water or methanol which

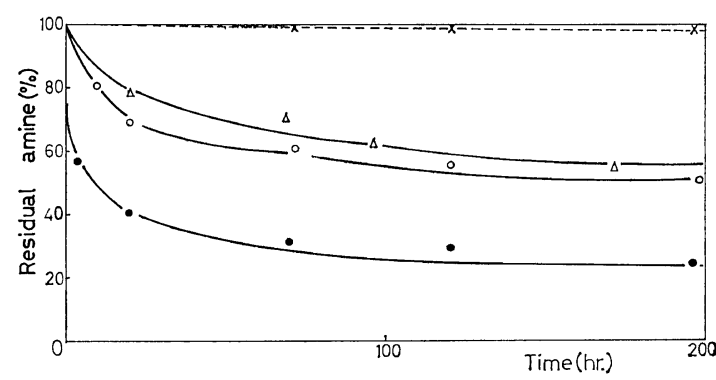

Figure 1. Polycondensation of monomer $\mathbf{I}$ with hexamethylenediamine in various solvents at $30^{\circ} \mathrm{C}$ : monomer concn, $1 \mathrm{~mol} / l$; (O), THF; $(\triangle), \mathrm{DMF}$; ( $)$, $\mathrm{CH}_{3} \mathrm{OH}$; ----, dimethyl adipate in methanol.

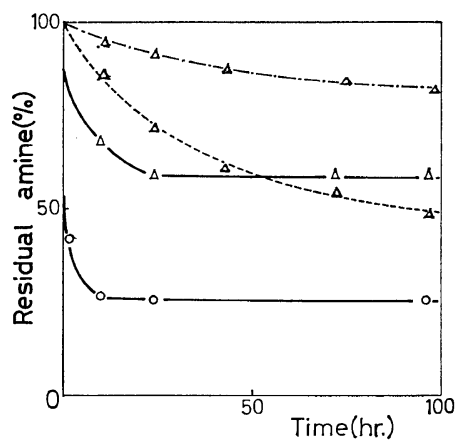

Figure 2. Polycondensation of monomers II, III, or IV with hexamethylenediamine in water or methanol at $30^{\circ} \mathrm{C}$ : monomer concn, $1 \mathrm{~mol} / l ;(O)$, $\mathrm{H}_{2} \mathrm{O} ;(\triangle), \mathrm{CH}_{3} \mathrm{OH} ;-\ldots$, monomer II; ----, monomer III; -.-.-, monomer IV. 
Active Polycondensation

Table I. Polycondensation of diesters having $\beta$-oxygen and $\beta$-sulfur atoms with hexamethylenediamine in various solvents at $30^{\circ} \mathrm{Ca}^{\mathrm{a}}$

\begin{tabular}{|c|c|c|c|c|c|}
\hline \multirow{2}{*}{ Monomer } & \multirow{2}{*}{ Solvent } & \multirow{2}{*}{ Time, day } & \multicolumn{3}{|c|}{ Polymer } \\
\hline & & & Yield, $\%$ & $M W$ & $\mathrm{mp},{ }^{\circ} \mathrm{C}$ \\
\hline \multirow{3}{*}{ Monomer I } & DMF & 16 & 57 & 650 & Grease \\
\hline & THF & 18 & 67 & 770 & Grease \\
\hline & Methanol & 25 & 55 & 820 & Grease \\
\hline \multirow[t]{3}{*}{ Monomer II } & Methanol & 5 & 42 & 1200 & $181-184$ \\
\hline & Water & 9 & 10 & 400 & $139-147$ \\
\hline & DMF & 22 & 7 & - & $184-192$ \\
\hline \multirow[t]{2}{*}{ Monomer III } & Methanol & 5 & 53 & 1200 & $149-164$ \\
\hline & NMP & 29 & 35 & 1600 & $154-158$ \\
\hline Monomer IV & DMF & 15 & 47 & - & $210(\mathrm{dec})$ \\
\hline
\end{tabular}

a Monomer concn, $1 \mathrm{~mol} / l$.

are eliminated products resulting from the polycondensation. This indicates that these polycondensation reactions are shifted toward polymer formation.

Comparing the results of Figure 1 with those of Figure 2, the polycondensation rate of monomer $I$ which has a $\beta$-oxygen atom is found to be faster than those of monomers II, III or IV which contain $\beta$-sulfur atoms. Furthermore, the reactivity among monomers II, III and IV can be arranged in the order: Monomer II $>$ Monomer III $>$ Monomer IV.

The polymer resulting from monomer I was a greasy solid without a distinct melting point, while those from monomers II, III and IV were yellow solids with sharp melting points, as shown in Table I. All of the polymers exhibited infrared spectral absorptions typical for their amide group and the elementary analyses of the polymers supported the structure of the corresponding polyamides.

Monomers Having $\beta$-Nitrogen or $\beta$-Phorphorus Atoms. When monomers V to IX, which contain a piperazine unit, were subjected to polycondensation reactions with hexamethylenediamine in methanol at $30^{\circ} \mathrm{C}$, the yield of the resulting polymers reached only a few percent. The reactivity of these monomers is considerably lower than that of the monomers having $\beta$-oxygen or $\beta$-sulfur atoms. Therefore, bulk polycondensation of these monomers with hexamethylenediamine or ethylenediamine was carried out at $110^{\circ} \mathrm{C}$ in order to compare their reactivities with the polymerizability of ordinary diesters such as di- methyl adipate. Figure 3 shows the polycondensation rates in terms of polymer yield versus time, and results of the polycondensation are summarized in comparison with the polycondensation of dimethyl or diphenyl adipate with hexamethylenediamine, as indicated in Table II.

Figure 3 indicates that the yield of acetoneinsoluble polymers was subject to change depending on the kind of ester alkoxy group and that the order of reactivities of these diesters in terms of polymer yields decreased as follows: phenyl ester $>$ methyl ester $>$ ethyl ester $>n$-butyl ester. This order is consistent with the reactivity of active esters toward nucleophilic replacement, as well recognized. On the other hand, when ethylenediamine was used, polymer yields from monomer $\mathrm{V}$ which is the methyl ester were larger

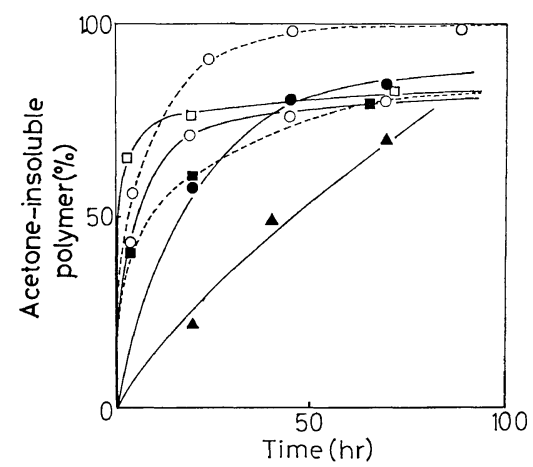

Figure 3. Polycondensation of monomers having a piperazine unit with diamines at $110^{\circ} \mathrm{C}$ : (O), monomer V; ( $)$, monomer VI; ( $\Delta)$, monomer VII; (घ), monomer VIII; — $\longrightarrow$, hexamethylenediamine; -_-_, ethylenediamine. 
N. Ogata, K. Sanur, and K. OKouchi

Table II. Bulk polycondensation of monomers having $\beta$-nitrogen with hexamethylenediamine

\begin{tabular}{|c|c|c|c|c|c|}
\hline \multirow{2}{*}{ Monomer } & \multirow{2}{*}{ Temp, ${ }^{\circ} \mathrm{C}$} & \multirow{2}{*}{ Time, hr } & \multicolumn{3}{|c|}{ Acetone-insoluble polymer } \\
\hline & & & $\eta_{\text {inh }}$ & Yield, \% & $\mathrm{mp},{ }^{\circ} \mathrm{C}$ \\
\hline \multirow[t]{6}{*}{ Monomer V } & 60 & 19.5 & 0.18 & 41 & \\
\hline & 60 & 66 & 0.19 & 83 & \\
\hline & 60 & 141 & 0.20 & 87 & $193-198$ \\
\hline & 110 & 19.5 & 0.22 & 72 & \\
\hline & 110 & 45 & 0.23 & 76 & \\
\hline & 110 & 70 & 0.25 & 80 & \\
\hline \multirow[t]{3}{*}{ Monomer VI } & 110 & 20.5 & 0.16 & 58 & \\
\hline & 110 & 45 & 0.22 & 81 & \\
\hline & 110 & 68.5 & 0.24 & 86 & \\
\hline \multirow[t]{3}{*}{ Monomer VII } & 110 & 40 & 0.21 & 49 & \\
\hline & 110 & 65 & 0.30 & 80 & \\
\hline & 110 & 115 & 0.36 & 90 & $201-205$ \\
\hline \multirow[t]{3}{*}{ Monomer VIII } & 110 & 3 & 0.50 & 66 & \\
\hline & 110 & 19.5 & 0.51 & 77 & \\
\hline & 110 & 72 & 0.52 & 83 & $185-193$ \\
\hline \multirow[t]{3}{*}{ Monomer IX } & 110 & 3 & 0.31 & 47 & \\
\hline & 110 & 19.5 & 0.31 & 49 & \\
\hline & 110 & 70 & 0.51 & 60 & $203-209$ \\
\hline \multirow[t]{3}{*}{ Methyl adipate } & 60 & 19.5 & 0.07 & 26 & \\
\hline & 60 & 69 & 0.09 & 75 & \\
\hline & 60 & 191 & 0.13 & 80 & $260-265$ \\
\hline \multirow[t]{3}{*}{ Phenyl adipate } & 110 & 3 & 0.32 & 92 & \\
\hline & 110 & 19.5 & 0.32 & 93 & \\
\hline & 110 & 70 & 0.34 & 98 & \\
\hline
\end{tabular}

than those from monomer VIII which is the

Table II shows that the yields of acetonephenyl ester. The cause of this difference in insoluble polymers increased with time, while the polymer yields between hexamethylenediamine increase of solution viscosities of the polymers and ethylenediamine is not yet clear. was very slow. This effect might be attributed

Table III. Bulk polycondensation of monomers having $\beta$-nitrogen atoms with various diamines at $110^{\circ} \mathrm{C}$

\begin{tabular}{|c|c|c|c|c|c|}
\hline \multirow{2}{*}{ Monomer } & \multirow{2}{*}{ Diamine } & \multirow{2}{*}{ Time, hr } & \multicolumn{3}{|c|}{ Polymer } \\
\hline & & & $\eta_{\text {inh }}$ & Yield, \% & $\mathrm{mp},{ }^{\circ} \mathrm{C}$ \\
\hline \multirow[t]{3}{*}{ Monomer V } & Ethylenediamine & 24 & 0.19 & 92 & \\
\hline & & 46 & 0.24 & 98 & \\
\hline & & 90.5 & 0.26 & 100 & $244-251$ \\
\hline Monomer V & 4,4'-Diamino diphenylether & 24 & - & 0 & - \\
\hline \multirow[t]{3}{*}{ Monomer VIII } & Ethylenediamine & 3 & 0.25 & 41 & \\
\hline & & 20 & 0.28 & 61 & \\
\hline & & 70 & 0.31 & 70 & $218-222$ \\
\hline \multirow[t]{3}{*}{ Monomer VIII } & $m$-Xylylenediamine & 3 & 0.41 & 70 & \\
\hline & & 44 & 0.55 & 73 & \\
\hline & & 89 & 0.61 & 75 & $191-195$ \\
\hline \multirow[t]{3}{*}{ Monomer VIII } & Piperazine & 3 & 0.28 & 60 & \\
\hline & & 20 & 0.29 & 67 & \\
\hline & & 70 & 0.32 & 76 & $218-226$ \\
\hline
\end{tabular}


to the heterogeneous-phase system for the polycondensation since the polymers precipitated out of the reaction systems so that the propagation reaction did not proceed further.

Results of the bulk polycondensation of monomers V to VIII with various diamines are collected in Table III. It should be noted that $m$-xylylenediamine yields a high-molecular-weight polymer.

As indicated in Table III, it was found that the reactivity of monomer $\mathrm{V}$, which is the dimethyl ester containing a piperazine unit, was higher than that of dimethyl adipate, while diphenyl adipate reacted with a faster rate than monomer VIII which is the diphenyl ester containing a piperazine unit. The apparent slow rate for the polycondensation of monomer VIII might be attributed to a higher melting point $\left(105^{\circ} \mathrm{C}\right)$ for this monomer since the reactive phase became heterogeneous soon after the monomer melted at the reaction temperature of $110^{\circ} \mathrm{C}$. On the other hand, the reactive phase for diphenyl adipate remained homogeneous probably due to the lower melting point and to the liberated phenol which might act as a solvent for the resulting polymer.

Results for the polycondensation of monomer IX, which has a substituted piperazine unit, are shown in Table II, where it is indicated that the polymer yields from monomer IX are inferior to those from monomer VIII. The lower reactivity of monomer IX might presumably be attributed to the steric hindrance of the two methyl groups on the piperazine unit.

Results for the polycondensation of monomers $\mathrm{X}, \mathrm{XI}$ and XII with hexamethylenediamine are summarized in Table IV. As is indicated in the Table, since the yield of acetone-insoluble polymers from these monomers was low, these monomers, which have aliphatic tertiary amines in the monomer structures, have lower reactivities than monomer $\mathrm{V}$ which has a piperazine unit. End-group titration confirmed that the acetonesoluble products from these monomers consisted in a large part of monomers. Therefore, the reactivity comparison in terms of the yield of acetone-insoluble polymers is presumed to be adequate for these monomers having tertiary amine and piperazine structures.

Table IV indicates that monomer XI which has an ethyl substituent on the nitrogen atom did not polycondensate and the difference in reactivity between methyl and ethyl substituents on the amine nitrogen atom was found to be great. This difference might be due to a steric hindrance.

Solution polycondensation of monomers XIII, $\mathrm{XIV}$ and $\mathrm{XV}$, which contain phosphorous atoms, were carried out in various solvents at room temperature over a few weeks and bulk poly-

Table IV. Bulk polycondensation of monomers having a substituted piperazine unit or an aliphatic tertiary amine unit with hexamethylenediamine

\begin{tabular}{lccccc}
\hline \multirow{2}{*}{ Monomer } & Temp, ${ }^{\circ} \mathrm{C}$ & Time, hr & \multicolumn{3}{c}{ Polymer } \\
\cline { 4 - 6 } Monomer X & 60 & 72 & 26 & - & Yield, $\%$ \\
& 60 & 120 & 41 & 0.19 & \\
& 60 & 192 & 44 & 0.21 & $185-194$ \\
& 110 & 20 & 33 & 0.28 & \\
Monomer XI & 110 & 70 & 58 & 0.32 & $179-186$ \\
& 110 & 120 & 68 & 0.33 & \\
Monomer XII & 110 & 20 & 3 & - & \\
& 110 & 72 & 4 & - & grease \\
& 110 & 144 & 5 & 0.09 & \\
& 110 & 240 & 9 & 0.20 & \\
& 110 & 20 & 41 & 0.26 & \\
& 110 & 70 & 54 & 0.30 & 179 \\
\hline
\end{tabular}


N. Ogata, K. Sanui, and K. OKouchi

Table V. Molten polycondensation of monomers having $\beta$-phosphorous atoms with hexamethylenediamine

\begin{tabular}{lcccccc}
\hline \multirow{2}{*}{ Monomer } & $\begin{array}{c}\text { Catalyst, } \\
2 \text { mol\% }\end{array}$ & Temp, ${ }^{\circ} \mathrm{C}$ & Time, hr & \multicolumn{3}{c}{ Polymer } \\
\cline { 5 - 7 } Monomer XIII & - & 60 & 50 & 0 & - & \\
& - & 110 & 40 & 76 & 0.05 & \\
Monomer XIV & - & 182 & 40 & 74 & 0.09 & \\
& $\mathrm{H}_{3} \mathrm{PO}_{4}$ & 182 & 20 & 52 & 0.19 & $102-110$ \\
& $\mathrm{AlEt}_{2} \mathrm{Cl}$ & 182 & 20 & 24 & 0.16 & $71-80$ \\
& $\mathrm{TiCl}_{4}$ & 182 & 20 & 49 & 0.13 & \\
& $\mathrm{ZnEt}_{2}$ & 182 & 20 & 32 & 0.13 & \\
Monomer XV & 182 & 20 & 56 & 0.13 & \\
& $\mathrm{SnCl}_{4}$ & 182 & 20 & 89 & 0.16 & \\
& $\mathrm{H}_{3} \mathrm{PO}_{4}$ & 182 & 3 & 87 & 0.19 & \\
& $\mathrm{AlEt}_{2} \mathrm{Cl}$ & 182 & 3 & 98 & 0.18 & \\
& $\mathrm{TiCl}_{4}$ & 182 & 3 & 69 & 0.21 & \\
& $\mathrm{ZnEt}_{2}$ & 182 & 3 & 84 & 0.20 & \\
& $\mathrm{SnCl}_{4}$ & 182 & 3 & 86 & 0.19 & \\
& $\mathrm{AlCl}_{3}$ & 182 & 3 & 81 & 0.17 & \\
\hline
\end{tabular}

condensations at 60 and $110^{\circ} \mathrm{C}$ were also carried out. However, results were negative as far as the reactivity of those monomers was concerned since they showed almost the same polymerizability with that of ordinary diesters such as dimethyl adipate. Therefore, melt polycondensation of these monomers with hexamethylenediamine was carried out at elevated temperatures as indicated in Table $\mathrm{V}$.

Monomer XV produced polyamide in a good yield when compared with monomers XIII and XIV. Since monomers VIII and XIV, which have trivalent phosphite groups, were found to be subject to thermal decomposition when heated above $150^{\circ} \mathrm{C}$, the high yield from monomer $\mathrm{XV}$ is presumed to be due not to reactivity enhancement, but to high thermal stability.

Comparing the polycondensation reactions of diesters having hetero atoms at the $\beta$ position, the reactivity enhancement of these monomers owing to hetero atoms could generally be arranged in the following order:

$$
-\mathrm{O}-\geq-\mathrm{S}->-\mathrm{N}=>-\mathrm{SO}_{2}->-\mathrm{P}=
$$

This order corresponds with the order of relative electronegativities of these hetero atoms. Since the absorptions due to the ester carbonyl group appeared at around $1720 \mathrm{~cm}^{-1}$ in the IR spectra of these diesters and no corelation was found between the carbonyl absorptions and the reactivity order, the reactivity enhancement by the $\beta$-hetero atoms is not due to the polarization of the ester carbonyl group. No confident reason for the effect of these hetero atoms on the reactivity enhancement is available and further investigation of the reaction mechanism is in progress.

\section{Polycondensation of Active Dibasic Acids}

The polycondensation reaction of monomer XVI with hexamethylenediamine did not take place in solution at $30^{\circ} \mathrm{C}$, indicating that the reactivity of a dibasic acid having a $\beta$-sulfur atom

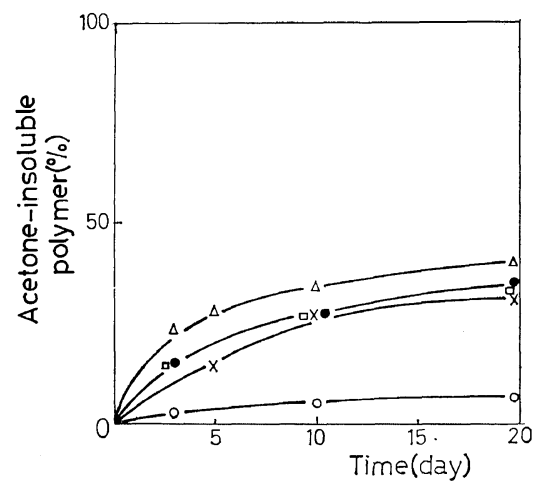

Figure 4. Solution polycondensation of monomer XVI with hexamethylenediamine at $100^{\circ} \mathrm{C}$ : monomer concn, $1 \mathrm{~mol} / l ;(\bigcirc), \mathrm{H}_{2} \mathrm{O} ;(\triangle), \mathrm{CH}_{3} \mathrm{OH} ;(\times)$, diisobutyl ketone; (@), DMF; ( $\square)$, HMPA. 
is much inferior to that of the corresponding diester having a $\beta$-sulfur atom. When the reaction temperature was raised to $100^{\circ} \mathrm{C}$, the polycondensation of monomer XVI took place with a slower rate than the polycondensation rate of monomer II, as indicated in Figure 4.

Solid-phase polycondensation of the nylon salts obtained from monomers XVI to XX and hexamethylenediamine was carried out at $150^{\circ} \mathrm{C}$ in nitrogen atomosphere and the results are shown in Figure 5 and Table VI.

The polycondensation of monomers XVI, XVII and XIX took place at $150^{\circ} \mathrm{C}$ with almost the same rate in terms of acetone-insoluble polymer yield, while hexamethylenediammonium adipate (nylon 66 salt) did not convert to the polyamide at all under the same conditions.

Monomer XX which contains a piperazine unit reacted to form polyamide with a slower rate than monomers XVI, XVII and XIX. When the thioether group of monomer XVII was oxidized to a sulfone group, the polycondensation rate decreased markedly as shown in Figure 5. Although the reactivity of these dibasic acids

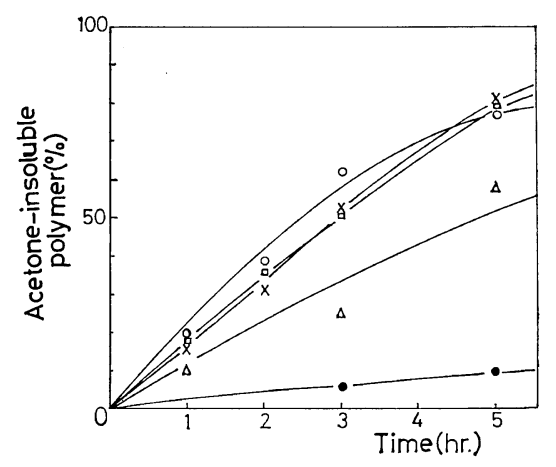

Figure 5. Solid-phase polycondensation of active dibasic acids with hexamethylenediamine at $150^{\circ} \mathrm{C}$ : $(\bigcirc)$, monomer XVI; $(x)$, monomer XVII; $(\bullet)$, monomer XVIII; $(\square)$, monomer XIX; $(\triangle)$, monomer XX.

having $\beta$-hetero atoms is much inferior to that of the corresponding diesters, these dibasic acids could be converted to the polyamide under mild conditions in comparison with the polycondensation of ordinary nylon salts such as hexamethylenediammonium adipate. The apparent reactivity order of these dibasic acids toward

Table VI. Solid-phase polycondensation of dibasic acids having $\beta$-hetero atoms with hexamethylenediamine

\begin{tabular}{|c|c|c|c|c|c|}
\hline \multirow{2}{*}{ Monomer } & \multirow{2}{*}{ Temp, ${ }^{\circ} \mathrm{C}$} & \multirow{2}{*}{ Time, hr } & \multicolumn{3}{|c|}{ Polymer } \\
\hline & & & Yield, $\%$ & $\eta_{\mathrm{inh}}$ & $\mathrm{mp},{ }^{\circ} \mathrm{C}$ \\
\hline \multirow{4}{*}{ Monomer XVI } & 150 & 1 & 19 & - & \\
\hline & 150 & 2 & 39 & - & \\
\hline & 150 & 3 & 63 & 0.12 & \\
\hline & 150 & 5 & 78 & 0.14 & $184-189$ \\
\hline \multirow[t]{4}{*}{ Monomer XVII } & 150 & 1 & 16 & - & \\
\hline & 150 & 2 & 31 & - & \\
\hline & 150 & 3 & 52 & 0.08 & \\
\hline & 150 & 5 & 81 & 0.11 & $194-198$ \\
\hline \multirow{3}{*}{ Monomer XVIII } & 150 & 1 & 0 & - & \\
\hline & 150 & 3 & 5 & - & \\
\hline & 150 & 5 & 10 & - & $242-248$ \\
\hline \multirow[t]{4}{*}{ Monomer XIX } & 150 & 1 & 18 & - & \\
\hline & 150 & 2 & 36 & - & \\
\hline & 150 & 3 & 50 & 0.08 & \\
\hline & 150 & 5 & 80 & 0.10 & Grease \\
\hline \multirow[t]{3}{*}{ Monomer XX } & 150 & 1 & 10 & - & \\
\hline & 150 & 3 & 25 & - & \\
\hline & 150 & 5 & 59 & 0.07 & Grease \\
\hline \multirow{3}{*}{$\begin{array}{l}\text { Hexamethylenediammonium } \\
\text { adipate }\end{array}$} & 150 & 1 & 0 & - & \\
\hline & 150 & 3 & 0 & - & \\
\hline & 150 & 5 & 5 & - & $230-240$ \\
\hline
\end{tabular}


polycondensation could be arranged as follows: $-\mathrm{O}->-\mathrm{S}->-\mathrm{N}=\gg-\mathrm{SO}_{2}-$. This order is the same as that of the corresponding diesters toward the nucleophilic replacement by aminolysis, as described previously.

\section{REFERENCES}

1. C. G. Overberger and J. Ševenda, J. Polym. Sci., Part A-1, 7, 2875 (1969).
2. N. Ogata, K. Sanui and K. Iijima, ibid., Chem. Ed., 11, 1095 (1973).

3. N. Ogata, ibid., Part C, No. 31, 217 (1970).

4. N. Ogata, K. Sanui, K. Okouchi, and T. Ikari, ibid., Part A-1, 10, 541 (1972).

5. "Organic Syntheses", Coll. Vol. 4, John Wiley \& Sons, Inc., New York, N.Y., 1963, p. 669.

6. "The Merck Index", 8th ed, Merck \& Co. Inc., Rahway, N.J. 1968, p. 1042. 